\title{
Article
}

Doi 10.5943/sif/5/1/20

\section{Preliminary studies on the lichens growing in FEEDS campus and SB garden in Manipur, India}

\author{
Nayaka $\mathrm{S}^{\mathbf{1}^{*}}$, Joseph $\mathrm{S}^{1}$, Ngangom $\mathrm{R}^{1}$, Tilotama $\mathrm{K}^{2}$ and Arnold $\mathrm{PK}^{2}$ \\ ${ }^{1}$ Lichenology Laboratory, CSIR-National Botanical Research Institute, Rana Pratap Marg, Lucknow 226 001, Uttar \\ Pradesh, India \\ ${ }^{2}$ Foundation for Environment and Economic Development Services (FEEDS), Hengbung, Kangpokpi-795 129, \\ Manipur, India
}

Nayaka S, Joseph S, Ngangom R, Tilotama K, Arnold PK 2020 - Preliminary studies on the lichens growing in FEEDS Campus and SB Garden, Hengbung. Studies in Fungi 5(1), 392-399, Doi 10.5943/sif/5/1/20

\begin{abstract}
In our continuous effort to explore the lichens in new and interesting areas FEEDS campus and SBG garden located in Manipur, a north-eastern state of India are surveyed. The study resulted in 47 species in FEEDS campus and 80 species in SB garden respectively, while both areas shared 22 species in common. The crustose lichens were more dominant in the area represented by Graphidaceae (16 spp.) and Pyrenulaceae (15 spp.). The species composition in both the sites represented photophilic communities such as graphidaceous, physcioid and parmelioid lichens. FEEDS campus had open areas with cultivated plants where as SBG garden had semi-evergreen forest at its initial stage of succession. The study also added 55 lichen species as new distributional records to Manipur.
\end{abstract}

Key words - Biodiversity - Lichenized fungi - Mycobiota - North-east India - Taxonomy

\section{Introduction}

North-east India consisting of eight states is undoubtedly a biodiversity hotspot in the country. Presence of Himalaya and its foothills make the region ecologically interesting with varied climate, edaphic and altitudinal gradients. The region hosts $50 \%$ of the flowering plants (ca. 8000 species), of which 2526 species are endemic (Tripathi et al. 2016). Likewise, the north-eastern region also has high diversity of lichens hosting approximately 1600 species, which is more than half of the known 2902 lichen species from the country (Sinha \& Jagadeesh Ram 2020). Among the north-eastern states Arunachal Pradesh, Assam and Sikkim are probably most extensively explored states for lichens, Manipur, Nagaland and Meghalaya are moderately explored, while Mizoram and Tripura are least explored states (Shukla et al. 2014). There has been a steady lichenological exploration in north-east region in the recent days and several novel or previously unreported species are being reported (Upreti et al. 2014, Singh et al. 2015, Singh \& Singh 2016, Logesh et al. 2017, Sinha \& Pooja 2017, Gogoi et al. 2019).

Lichens from Manipur were explored as early as 1880s. Dr. G. Watt, a European botanist collected lichens from Manipur during 1881-82 which were identified by Müller Argoviensis (1892) who reported 101 species including 29 new ones. Singh \& Sinha (2010) listed 292 species for Manipur in their book 'Indian lichens: An annotated checklist' from all the studies carried out in the state till then. Devi et al. (2013, 2015) documented 140 lichen species belonging to 50 genera 
and 23 families from various localities in Manipur. Singh \& Singh (2015) reported 11 species of Graphidaceae as new to Manipur. Addition of all these numbers sums up to 443 species of lichens so far reported from Manipur.

In our continuous effort to document lichen biota of the country with emphasis on remote areas, ecologically interesting and unexplored area in the present study 'Foundation for Environment and Economic Development Services (FEEDS)' and 'Sylvan Botanic Garden (SBG)' are surveyed (Fig. 1). FEEDS is a no-profit, non-government organization located in Hengbung,

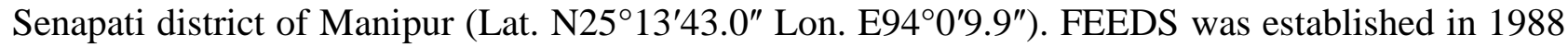
for promotion of sustainable farming among tribal communities as an alternative to shifting cultivation. SBG is a natural forest adopted by FEEDS for in situ and ex-situ conservation of identified species, research and education (Lat. N25'23'56.4" Lon. E93'99'86.9"). Both the sites are located about $10 \mathrm{~km}$ apart, but with similar altitude of approximately $1200 \mathrm{~m}$ from above mean sea level. FEEDS campus has thinner vegetation dominated by cultivated plants of horticultural importance. Whereas SBG has natural semi-evergreen forest with tall trees and undulating topography. In the present communication lichen diversity in these two regions are reported and ecological conditions of the area is discussed.

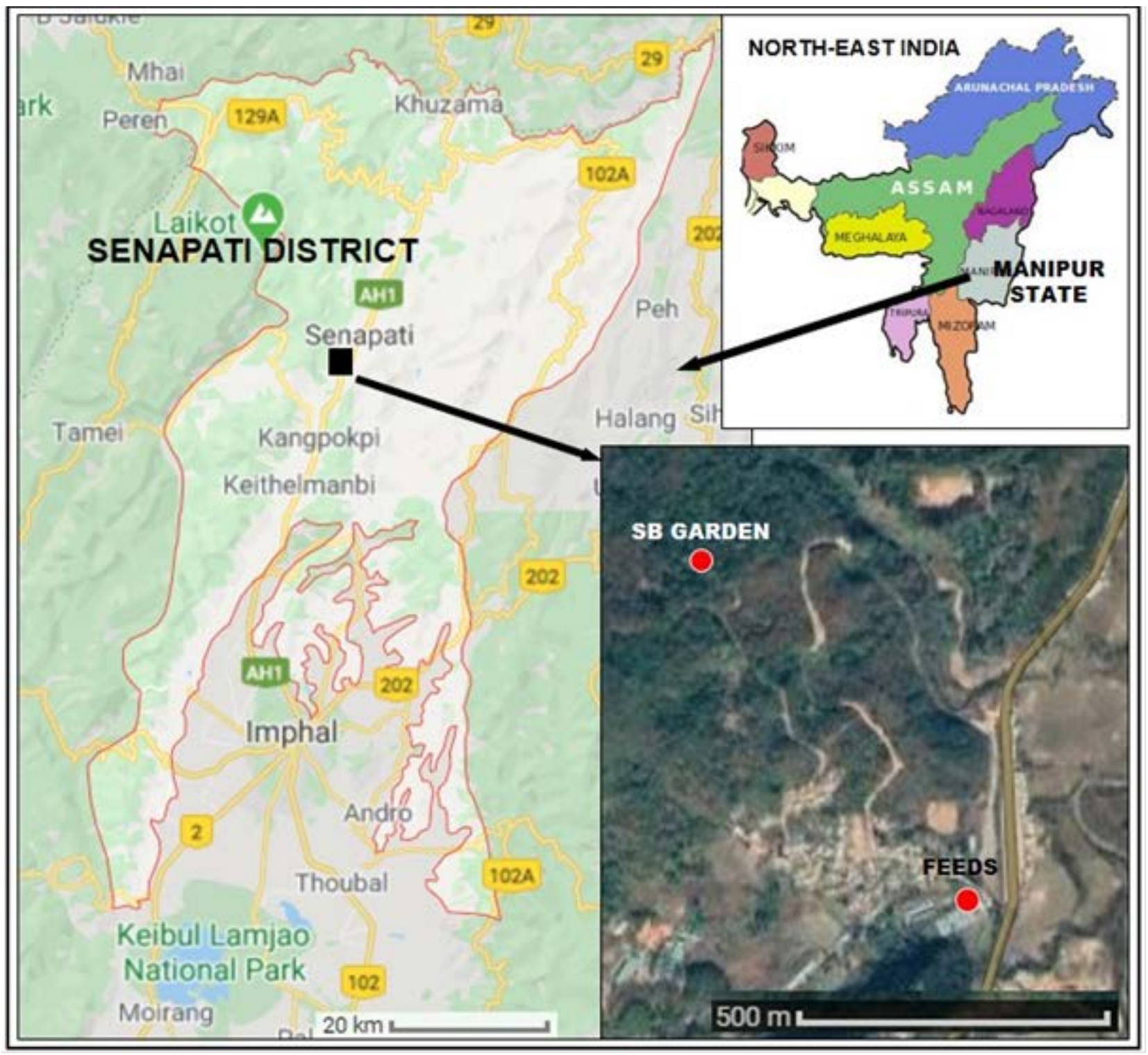

Fig. 1 - Map showing Manipur state within North-east India, Senapati district and location of SBG and FEEDS 


\section{Materials \& Methods}

Lichens from FEEDS campus and SBG were collected on $11^{\text {th }}$ and $12^{\text {th }}$ June 2018 respectively. A total of 250 specimens were collected from tree trunk, twigs, and soil. The specimens were thoroughly dried and preserved in the herbarium LWG of CSIR-National Botanical Research Institute, Lucknow with labels. Morphological and anatomical characters were examined using stereo zoom Leica S8APO and light DM2500 microscopes attached with camera. Thin, hand cut sections of thallus and ascomata were mounted in plain water and various measurements were taken under light microscope. Also, the sections were mounted in $10 \% \mathrm{KOH}$, Lugol's iodine and lactophenol cotton blue for detailed study of the structures. For spot tests the usual reagents of K, C and $\mathrm{P}$ were used and for identification of lichens substance by thin layer chromatography (TLC) was performed in solvent system C following Orange et al. (2001). The specimens were identified up to species level with the help of keys of Awasthi (1991, 2007), Aptroot (2012), Jagadeesh Ram (2014), Kalb et al. (2004), Lücking et al. (2009a) and Nayaka (2005). The recent classification compiled by Lücking et al. (2017) was followed segregate species into families. Recent nomenclatures are updated following Index Fungorum 2020.

FEEDS and SBG have different types of vegetations and therefore the lichen diversity between the two localities are analyzed separately. Further, to ascertain a meaning to the species composition in FEEDS and SBG the lichens are categorized into few major communities or functional groups such as type of growth forms (crustose, foliose, fruticose); cyanolichens (Coccocarpia, Leptogium, Pseudocyphelaria); graphidaceous (Diorygma, Glyphis, Graphis, Hemitheicum, Pallidogramme, Phaeographis); parmelioid (Bulbothrix, Hypotrachyna, Myelochroa, Parmelinella, Parmotrema, Remototrachyna); physcioid (Dirinaria, Heterodermia, Leucodermia, Phaeophyscia, Physcia, Polyblastidium, Pyxine) and pyrenocarpous (Anthracothecium, Pyrenula). The indications of these communities are interpreted following published literature (Koch et al. 2013, Rikkinen 2015).

\section{Result \& Discussion}

A total of 250 lichen samples were collected which resulted in 105 species under 48 genera and 24 families (Table 1). Out of the total SBG recorded more number of lichens represented by 80 species, FEEDS campus harboured 47 species while 22 species were common to both the sites. The crustose lichens are more dominant in both the localites with 60 species followed by foliose with 41 species. The fruticose lichens were very few in the area represented by four species. Similar trend of species composition was also seen in earlier studies by Devi et al. (2015) in Manipur where 50\% of crustose, $44 \%$ foliose and $6 \%$ of crustose lichens were recorded. It is interesting to note that Graphidaceae, Pyrenulaceae, Phyciaceae and Parmeliacae are the dominant families in whole study area with 16, 15, 15 and 14 species. Among the genera Pyrenula, Graphis and Heterodermia were dominant with 14, 10 and 9 species. These communities of lichens are typical representatives of tropical forest. Based on the general observation and number of specimens collected we can group the lichen in-to three categories; 1. Less common, 2. Common and 3. Most common. Maximum number of lichens (73) belongs less common category in the area while 22 are common. Bulbothrix isidiza, Haematomma accolens, Heterodermia albidiflava, $H$. comosa, $H$. diademata, Lecanora helva, Parmotrema indicum, P. reticulatum, P. tinctorum and Pseudocyphellaria crocata are the most common lichens in the area.

Table 1 List of lichens from FEEDS campus and SBG [Note: $\mathrm{CR}=$ Crustose, $\mathrm{FL}=$ Foliose, $\mathrm{FR}=$ Fruiticose, $+=$ Present, $*=$ new to Manipur state]

\begin{tabular}{|c|c|c|c|c|c|c|}
\hline & Species & Family & Habit & FEEDS & SBG & Remarks \\
\hline$\overline{1 *}$ & $\begin{array}{l}\text { Allographa epixantha (Mont. \& Bosch) Lücking \& } \\
\text { Kalb }\end{array}$ & Graphidaceae & CR & & + & Common \\
\hline $2 *$ & Anthracothecium prasinum (Eschw.) R.C. Harris & Pyrenulaceae & CR & + & + & Common \\
\hline $3 *$ & $\begin{array}{l}\text { Arthothelium confertum (A.L. Smith) Makhija \& } \\
\text { Patwrdhan }\end{array}$ & Arthoniaceae & CR & & + & Less common \\
\hline
\end{tabular}


Table 1 Continued.

\begin{tabular}{|c|c|c|c|c|c|c|}
\hline & Species & Family & Habit & FEEDS & SBG & Remarks \\
\hline 4 & Bacidia submedialis (Nyl.) Zahlbr. & Ramalinaceae & $\mathrm{CR}$ & + & & Common \\
\hline 5 & Bulbothrix isidiza (Nyl.) Hale & Parmeliaceae & FL & + & + & Most common \\
\hline 6 & B. setschwanensis (Zahlbr.) Hale & Parmeliaceae & FL & & + & Common \\
\hline 7 & Byssoloma subdiscordans (Nyl.) P. James & Pilocarpaceae & CR & + & & Less common \\
\hline 8 & Coniocarpon cinnabarinum DC. & Arthoniaceae & CR & + & & Less common \\
\hline $9 *$ & Cladonia coniocraea (Flörke) Spreng. & Cladoniaceae & FR & & + & Common \\
\hline $10 *$ & C. corniculata Ahti \& Kashiw. & Cladoniaceae & FR & + & & Common \\
\hline 11 & Coccocarpia erythroxyli (Spreng.) Swinscow \& Krog & Coccocarpiaceae & FL & & + & Less common \\
\hline $12 *$ & Diorygma hieroglyphicum (Pers.) Staiger \& Kalb & Graphidaceae & CR & + & & Common \\
\hline 13 & Dirinaria consimilis (Stirt.) D.D. Awasthi & Caliciaceae & FL & & + & Common \\
\hline 14 & Glyphis cicatricosa Ach. & Graphidaceae & CR & + & + & Common \\
\hline $15^{*}$ & Graphidastra multiformis (Mont. \& Bosch) G. Thor & Roccellaceae & CR & & + & Less common \\
\hline $16^{*}$ & Graphis brahmanensis Aptroot & Graphidaceae & CR & & + & Less common \\
\hline $17 *$ & G. chlorotica A. Massal. & Graphidaceae & CR & + & & Less common \\
\hline 18 & G. cincta (Pers.) Aptroot & Graphidaceae & CR & + & + & Common \\
\hline 19 & G. contortuplicata Müll. Arg. & Graphidaceae & CR & & + & Less common \\
\hline $20 *$ & G. elegans (Borrer ex Sm.) Ach. & Graphidaceae & CR & & + & Less common \\
\hline $21 *$ & G. handelii Zahlbr. & Graphidaceae & CR & + & + & Less common \\
\hline 22 & G. lineola Ach. & Graphidaceae & CR & + & + & Common \\
\hline 23 & G. scripta (L.) Ach. & Graphidaceae & CR & + & & Less common \\
\hline 24 & G. striatula (Ach.) Spreng. & Graphidaceae & CR & + & + & Less common \\
\hline $25 *$ & G. submarginata Lücking & Graphidaceae & CR & & + & Less common \\
\hline $26 *$ & Haematomma accolens (Stirt.) Hillmann & Haematommataceae & CR & & + & Most common \\
\hline $27 *$ & $\begin{array}{l}\text { Hemithecium epixanthum (Mont. \& Bosch) Chitale \& } \\
\text { Makhija }\end{array}$ & Graphidaceae & CR & & + & Less common \\
\hline $28 *$ & $\begin{array}{l}\text { Herpothallon echinatum Aptroot, Lücking \& Will- } \\
\text { Wolf }\end{array}$ & Arthoniaceae & CR & & + & Common \\
\hline $29 *$ & H. biacidum Frisch et al. & Arthoniaceae & CR & & + & Less Common \\
\hline 30 & Heterodermia albidiflava (Kurok.) D.D. Awasthi & Physciaceae & FL & + & + & Most common \\
\hline $31^{*}$ & H. antillarum (Vain.) Swinscow \& Krog & Physciaceae & FL & & + & Less common \\
\hline 32 & H. comosa (Eschw.) Follmann \& Redón & Physciaceae & FL & & + & Most common \\
\hline 33 & H. diademata (Taylor) D.D. Awasthi & Physciaceae & FL & + & + & Most common \\
\hline 34 & H. incana (Stirt.) D.D. Awasthi & Physciaceae & FL & & + & Less common \\
\hline 35 & H. obscurata (Nyl.) Trevis. & Physciaceae & FL & + & + & Common \\
\hline $36 *$ & H. speciosa (Wulfen) Trevis. & Physciaceae & FL & & + & Less common \\
\hline $37 *$ & Hypotrachyna nepalensis (Taylor) Divakar et al. & Parmeliaceae & FL & & + & Less common \\
\hline 30 & Lecanora allophana (Ach.) Nyl. & Lecanoraceae & CR & + & & Less common \\
\hline 39 & L. chlarotera Nyl. & Lecanoraceae & CR & + & + & Less common \\
\hline $40 *$ & L. helva Stizenb. & Lecanoraceae & CR & + & + & Most common \\
\hline $41^{*}$ & L. imshaugii Brodo & Lecanoraceae & CR & & + & Less common \\
\hline $42 *$ & L. interjecta Müll. Arg. & Lecanoraceae & CR & + & & Less common \\
\hline 43 & L. pulicaris (Pers.) Ach. & Lecanoraceae & CR & & + & Less common \\
\hline $44^{*}$ & Lepraria cupressicola (Hue) J.R. Laundon & Stereocaulaceae & CR & + & + & Less common \\
\hline $45^{*}$ & L. ecorticata (J.R. Laundon) Kukwa & Stereocaulaceae & CR & & + & Less common \\
\hline $46^{*}$ & L. lobificans Nyl. & Stereocaulaceae & CR & + & & Less common \\
\hline 47 & Leptogium austroamericanum (Malme) C.W. Dodge & Collemataceae & FL & & + & Less common \\
\hline $48 *$ & L. chloromelum (Sw.) Nyl. & Collemataceae & FL & & + & Less common \\
\hline $49 *$ & L. coralloideum (Meyen \& Flot.) Vain. & Collemataceae & FL & + & + & Common \\
\hline 50 & L. denticulatum Nyl. & Collemataceae & FL & & + & Common \\
\hline $51^{*}$ & L. phyllocarpum (Pers.) Mont. & Collemataceae & FL & & + & Common \\
\hline $52 *$ & Leucodermia leucomelos (L.) Kalb & Physciaceae & FL & & + & Less common \\
\hline 53 & Malmidea granifera (Ach.) Kalb et al. & Malmideaceae & CR & & + & Less common \\
\hline $54 *$ & M. papillosa Weerak. \& Aptroot & Malmideaceae & CR & & + & Less common \\
\hline $55^{*}$ & M. subaurigera (Vain.) Kalb et al. & Malmideaceae & CR & & + & Less common \\
\hline $56^{*}$ & Megalaria leptocheila (Tuck.) Fryday \& Lendermer & Ramalinaceae & CT & + & & Less common \\
\hline $57 *$ & Melaspilea gemella (Eschw.) Nyl. & Melaspileaceae & CR & + & & Less common \\
\hline 58 & Myelochroa aurulenta (Tuck.) Elix \& Hale & Parmeliaceae & FL & & + & Common \\
\hline $59 *$ & M. subaurulenta (Nyl.) Elix \& Hale & Parmeliaceae & FL & & + & Less common \\
\hline $60 *$ & Opegrapha dimidiata Müll. Arg. & Opegraphaceae & $\mathrm{CR}$ & & + & Less common \\
\hline
\end{tabular}


Table 1 Continued.

\begin{tabular}{|c|c|c|c|c|c|c|}
\hline & Species & Family & Habit & FEEDS & SBG & Remarks \\
\hline$\overline{61}$ & Pallidogramme chrysenteron (Mont.) Staige et al. & Graphidaceae & $\mathrm{CR}$ & & + & Less common \\
\hline 62 & Parmelinella wallichiana (Taylor) Elix \& Hale & Parmeliaceae & FL & + & & Less common \\
\hline 63 & Parmotrema austrosinense (Zahlbr.) Hale & Parmeliaceae & FL & & + & Common \\
\hline 64 & P. hababianum (Gyeln.) Hale & Parmeliaceae & FL & & + & Common \\
\hline 65 & P. indicum Hale & Parmeliaceae & FL & & + & Most common \\
\hline 66 & P. reticulatum (Taylor) M. Choisy & Parmeliaceae & FL & + & + & Most common \\
\hline 67 & P tinctorum (Nyl.) Hale & Parmeliaceae & FL & + & & Most common \\
\hline $68 *$ & Pertusaria erythrella Müll. Arg. & Pertusariaceae & CR & & + & Less common \\
\hline $69 *$ & P. pertusa (L.) Tuck. & Pertusariaceae & CR & + & & Less common \\
\hline $70 *$ & Phaeographis dendritica (Ach.) Müll. Arg. & Graphidaceae & $\mathrm{CR}$ & & + & Less common \\
\hline 71 & Phaeophyscia endococcina (Körb.) Moberg & Physciaceae & FL & & + & Less common \\
\hline 72 & P. hispidula var. exornatula (Zahlbr.) Moberg & Physciaceae & FL & + & & Less common \\
\hline 73 & P. pyrrhophora (Poelt) D.D. Awasthi & Physciaceae & FL & & + & Less common \\
\hline $74 *$ & Phyllopsora furfuracea (Pers.) Zahlbr. & Ramalinaceae & FL & & + & Less common \\
\hline 75 & Physcia dilatata Nyl. & Physciaceae & FL & & + & Less common \\
\hline $76^{*}$ & P. sorediosa (Vain.) Lynge & Physciaceae & FL & & + & Less common \\
\hline 77 & P. tribacioides Nyl. & Physciaceae & FL & + & & Less common \\
\hline 78 & Polyblastidium japonicum (M. Satô) Kalb & Physciaceae & FL & & + & Less common \\
\hline $79 *$ & Pseudocyphellaria crocata (L.) Vain. & Lobariaceae & FL & & + & Most common \\
\hline $80 *$ & Pyrenula andina Aptroot & Pyrenulaceae & CR & + & + & Less common \\
\hline $81 *$ & P. bahiana Malme & Pyrenulaceae & CR & + & & Less common \\
\hline 82 & P. breutelii (Müll. Arg.) Aptroot & Pyrenulaceae & CR & + & & Less common \\
\hline 83* & P. chlorospila (Nyl.) Arnold & Pyrenulaceae & CR & + & & Less common \\
\hline $84 *$ & P. dissimulans (Müll. Arg.) R.C. Harris & Pyrenulaceae & CR & + & & Less common \\
\hline 85 & P. immissa (Stirt.) Zahlbr. & Pyrenulaceae & CR & & + & Common \\
\hline 86 & P. leucostoma Ach. & Pyrenulaceae & $\mathrm{CR}$ & & + & Less common \\
\hline $87 *$ & P. macrospora (Degel.) Coppins \& James & Pyrenulaceae & CR & & + & Less common \\
\hline 88* & P. massariospora (Starbäck) R.C. Harris & Pyrenulaceae & CR & & + & Less common \\
\hline $89 *$ & P. mastophoroides (Nyl.) Zahlbr. & Pyrenulaceae & CR & + & + & Common \\
\hline $90 *$ & P. microspora (Nagarkar \& Patw.) Upreti & Pyrenulaceae & $\mathrm{CR}$ & + & & Less common \\
\hline $91^{*}$ & P. oculata A. Singh \& Upreti & Pyrenulaceae & CR & + & & Less common \\
\hline 92 & P. pyrenuloides (Mont.) R.C. Harris & Pyrenulaceae & CR & & + & Less common \\
\hline 93* & P. subelliptica (Tuck.) R.C. Harris & Pyrenulaceae & CR & & + & Less common \\
\hline 94 & Pyxine meissnerina Nyl. & Caliciaceae & FL & & + & Less common \\
\hline 95 & P. reticulata (Vain.) Vain. & Caliciaceae & FL & + & & Less common \\
\hline 96 & P. sorediata (Ach.) Mont. & Caliciaceae & FL & & + & Less common \\
\hline 97 & P. subcinerea Stirt. & Caliciaceae & FL & + & & Less common \\
\hline 98 & Ramalina conduplicans Vain. & Ramalinaceae & FR & & + & Common \\
\hline 99 & Ramboldia manipurensis (Kr.P. Singh) Kalb et al. & Ramboldiaceae & $\mathrm{CR}$ & & + & Less common \\
\hline 100 & $\begin{array}{l}\text { Remototrachyna infirma (Kurok.) Divakar \& A. } \\
\text { Crespo }\end{array}$ & Parmeliaceae & FL & + & + & Less common \\
\hline $101^{*}$ & R. thryptica (Hale) Divakar \& A. Crespo & Parmeliaceae & FL & & + & Less common \\
\hline $102 *$ & Sculptolumina japonica (Tuck.) Marbach & Caliciaceae & $\mathrm{CR}$ & + & & Less common \\
\hline 103 & Sphinctrina tubaeformis A. Massal. & Sphinctrinaceae & CR & & + & Less common \\
\hline $104 *$ & Tylophoron moderatum Nyl. & Arthoniaceae & CR & & + & Less common \\
\hline $105 *$ & Usnea stigmatoides G. Awasthi & Parmeliaceae & FR & & + & Less common \\
\hline
\end{tabular}

The present study added a total of 55 species as new to Manipur state. As mentioned earlier only 22 species are common between two areas while 25 species are restricted to FEEDS and 58 are found only in SBG. In both the sites proportion of crustose lichens is more followed by foliose forms. The lichen communities are functional groups categorized for the present study is given in Table 2. It can be seen that SBG has more number of cyanolichens in comparison to FEEDS. The cyanolichens are indicators of presence of high humidity and old-growth forest conditions (Scheidegger et al. 2002) as they have specialized habitat requirements (Rikkinen 2015). Lobaria pulmonaria, an epiphytic cyanolichen is frequently used as indicator species to identify forests of high conservation priority and ecological continuity (Scheidegger \& Werth 2009). Present study clearly indicates that SBG has much humid conditions conducive for luxuriant growth of lichens. 
Table 2 Proportion of various lichen communities in FEEDS and SBG

\begin{tabular}{|l|l|l|}
\hline \multicolumn{1}{|c|}{ Lichen communities } & FEEDS (\%) & SBG (\%) \\
\hline Crustose & 61.7 & 55 \\
\hline Foliose & 36.2 & 41.3 \\
\hline Fruticose & 2.1 & 3.7 \\
\hline Cyanolichens & 2.1 & 8.7 \\
\hline Graphidaceous & 17 & 16.3 \\
\hline Parmelioid & 17 & 13.7 \\
\hline Physcioid & 17 & 20 \\
\hline Pyrenocarpous & 19.1 & 11.3 \\
\hline
\end{tabular}

The species composition of an area responds to changes in the local ecological conditions, which can be used as good indicator of forest regeneration and ecological continuity (Plata et al. 2008, Koch et al. 2013). Ecological continuity refers to the time span a forest ecosystem requires to reach dynamic equilibrium of succession. Koch et al. (2013) studied lichens in three succession stage tropical forest in Brazil. Accordingly, the dominance of crustose lichens and pyrenocarpous (perithecia bearing) lichens are the indication of forest's late succession stage (mature forest) with low light and wind speed, but high humidity. The crustose lichens are tolerant to low luminosity and have high hydrophobicity. Reproduction through perithecia is suitable in mature forest because they do not depend on wind for spore dispersal. On the hand foliose, fruticose and graphidaceous lichens are indicators of initial succession. These foliose and fruticose lichens require light and lower humidity. As the light decreases in the forest they tend migrate to the canopy of the forest. These groups of lichens also can rehydrate and lose water quickly. In such condition crustose lichens are weak competitors (Ellis \& Coppins 2006). Whereas in case of graphidaceous lichens their labia (lirella's margin), usually black and closed, grant them protection to excessive light and to dryness in areas of early succession. Further, these lichens need to be exposed to light in order to produce spores (Koch et al. 2013). In the present study both the sites had more number of foliose lichens, especially light loving parmelioid (17 and 13.7\%) and physcioid lichens (17 and 20\%). Further, both the sites represented equal proportion of graphidaceous lichens (17 and 16.3\%). Such a result is obvious for FEEDS because the site had lots of open areas with cultivated plants and building construction. Whereas SBG although had a humid, semi-evergreen kind of forest it is still in initial stage of succession. It is also possible that SBG may be secondary regenerated forest which was once subjected shifting cultivation. The shifting cultivation (also called as Jhum or Paamlou in local language) was a well documented practice in the Manipur region (Reimeingam 2017). As mentioned earlier both the sites had luxuriant growth of lichens. Also, the proportion of pyrenocarpous lichens are more in FEEDS campus. However, both cannot be considered as indicator of mature forest. It is observed that in tropical countries proportion of crustose lichens are always higher than foliose and fruticose (Lücking et al. 2009b). Any study in such case would yield more number of crustose lichens. A large number of quantitative studies are required to draw conclusion based on crustose lichens. In case of pyrenocarpous lichens characteristic of FEEDS campus do not indicate it as a mature forest.

\section{Conclusion}

Tropical forests in the world are not only the major resource for livelihood but also most threatened diversity hotspots (Myers et al. 2000). The highest species richness of lichens is found in the tropical rain forests around the world and $500-600$ or more species can be found just within a $\mathrm{km}^{2}$ (Lücking et al. 2011). There are more lichen species than tree or bird species in any given area of tropical jungle. Unfortunately, $50 \%$ of the tropical forest are unexplored for lichens (Aptroot \& Sipman 1997). It is evident from the present study that SBG has rich diversity of lichens and there is a need for intensive survey in the area. It can be mentioned here that Herpothallon biacidum, Malmidea papillosa and Pertusaria erythrella are described as new record to India from the same collection (Ingle et al. in prep.). The SBG and surrounding area gives an opportunity to study the 
effect of shifting cultivation on lichen communities. Several indicator communities can be identified from detailed studies in forests of various regeneration stage. Such studies not only yield valuable publications but also will be a baseline for future biomonitoring studies.

\section{Acknowledgements}

We thank Director, CSIR - National Botanical Research Institute, Lucknow for providing Laboratory facilities; Mr Haokholet Kipgen, President, FEEDS and Dr. A.K.S Rawat, Executive Director, Ethnomedicinal Research Centre (EMRC), Hengbung, Senapati for providing necessary logistic support and facilities for conducting survey; Science and Engineering Board (SERB), New Delhi for financial assistance under project no. EMR/2016/006604 to SN and NPDF Fellowship no. PDF/2016/002054 to SJ. The author (SJ) is also thankful to DST, New Delhi for the financial assistance under INSPIRE Faculty scheme (IFA18-LSPA 124). (Manuscript number: CSIRNBRI_MS/2020/05/11).

\section{References}

Aptroot A. 2012 - A world key to the species of Anthracothecium and Pyrenula. The Lichenologist 44(1), 5-33. Doi: 10.1017/S0024282911000624

Aptroot A, Sipman HJM. 1997 - Diversity of lichenized fungi in the tropics. In: Hyde KD (ed), Biodiversity of Tropical Microfungi. University Press, Hong Kong, pp. 93-106.

Awasthi DD. 1991 - A key to the microlichens of India, Nepal and Sri Lanka. Bibliotheca Lichenologica 40, 1-136.

Awasthi DD. 2007 - A Compendium of the Macrolichens from India, Nepal and Sri Lanka. Bishen Singh Mahendra Pal Singh, Dehradun, India.

Devi RKS, Rout J, Upreti DK, Nayaka S, Pinokiyo A. 2015 - New records of lichens from Manipur State, North-eastern India. Mycosphere 6(6), 796-813.

Doi: 10.5943/mycosphere/6/6/13

Devi RKS, Rout J, Upreti DK, Pinokiyo A. 2013 - New additions to the microlichens of Manipur, North East India. Phytotaxonomy 13, 75-83.

Ellis CJ, Coppins BJ. 2006 - Contrasting functional traits maintain lichen epiphyte diversity in response to climate and autogenic succession. Journal of Biogeography 33(9), 1643-1656. Doi: 10.1111/j.1365-2699.2006.01522.x

Gogoi R, Joseph S, Nayaka S, Yasmin F. 2019 - Addition to the lichen biota of Assam State, India. J. Threatened Taxa 11(6), 13765-13781. Doi: 10.11609/jott.4642.11.6.13765-1378

Index Fungorum. 2020 - www.indexfungorum.com (accessed on 11 February 2020)

Jagadeesh Ram TAM. 2014 - The genus Herpothallon (Arthoniaceae) in the Andaman Islands, India. The Lichenologist 46(1), 39-49. Doi: 10.1017/S0024282913000571

Kalb K, Staiger B, Elix J. 2004 - A monograph of the lichen genus Diorygma - A first attempt. Symbolae Botanicae Upsalienses 34(1), 133-181.

Koch NM, Martins SMDA, Lucheta F, Müller SC. 2013 - Functional diversity and traits assembly patterns of lichens as indicators of successional stages in a tropical rainforest. Ecological Indicators 34, 22-30. Doi: 10.1016/j.ecolind.2013.04.012

Logesh AR, Chinlampianga M, Shukla AC, Upreti DK. 2017 - Studies on lichens of Mizoram, northeast India. Proceedings of the National Academy of Sciences, India Section B: Biological Sciences 87(2), 445-457. Doi: 10.1007/s40011-015-0592-z

Lücking R, Archer AW, Aptroot A. 2009a - A world-wide key to the genus Graphis (Ostropales: Graphidaceae). The Lichenologist 41(4), 363-452. Doi: 10.1017/S0024282909008305

Lücking R, Hodkinson BP, Leavitt SD. 2017 - The 2016 classification of lichenized fungi in the Ascomycota and Basidiomycota - Approaching one thousand genera. The Bryologist 119(4), 361-416. Doi: 10.1639/0007-2745-119.4.361

Lücking R, Rivas Plata E, Chaves JL, Umaña L, Sipman HJM. 2009b - How many tropical lichens are there ... really? In: Thell A, Seaward MRD, Feuerer T (eds), Diversity of lichenology - 
Jubilee volume. Bibliotheca Lichenologica No. 100. J. Cramer in der Gebrüder Borntraeger Verlagsbuchhandlung, Berlin and Stuttgart, pp. 399-418.

Lücking R, Seavey F, Common R, Beeching SQ et al. 2011 - The lichens of Fakahatchee Strand Preserve State Park, Florida: Proceedings from the $18^{\text {th }}$ Tuckerman Workshop. Bulletin of the Florida Museum of Natural History 49(4), 127-186.

Myers N, Mittermeier RA, Mittermeier CG, Fonseca GAB, Kent J. 2000 - Biodiversity hotspots for conservation priorities. Nature 403, 854-858. DOI: 10.1038/35002501

Müller Agroviensis J. 1892 - Lichenes Manipurenses, a cl. Dr. G. Watt circa Manipur, ad limites orientales Indiæ Orientalis 1881-1882, lecti. Botanical Journal of the Linnean Society 29(201), 217-231.

Nayaka S. 2005 - Revisionary studies on lichen genus Lecanora sensu lato in India. Dr. R.M.L. Avadh University, Faizabad, India (Ph.D. Thesis).

Orange A, James PW, White FJ. 2001 - Microchemical methods for the identification of lichens. British Lichen Society, London.

Reimeingam M. 2017 - Shifting cultivation in Manipur: Land, labour and environment. Journal of Rural Development 36(1), 97-119.

Rikkinen J. 2015 - Cyanolichens. Biodiversity and Conservation 24(4), 973-993. Doi: 10.1007/s10531-015-0906-8

Plata RE, Lücking R, Lumbsch HT. 2008 - When family matters: an analysis of Thelotremataceae (Lichenized Ascomycota: Ostropales) as bioindicators of ecological continuity in tropical forests. Biodiversity and Conservation 17(6), 1319-1351. Doi: 10.1007/s10531-007-9289-9

Scheidegger C, Groner U, Keller C, Stofer S. 2002 - Biodiversity assessment tools - Lichens. In: Nimis PL, Scheidegger C, Wolseley PA (eds.), Monitoring with Lichens - Monitoring Lichens. Nato Science Series. IV, Earth and Environmental Sciences, Kluwer Academic Publishers, Dordrecht, Netherlands, pp. 359-365.

Scheidegger C, Werth S. 2009 - Conservation strategies for lichens: Insights from population biology. Fungal Biology Reviews 23(3), 55-66. Doi: 10.1016/j.fbr.2009.10.003

Shukla V, Upreti DK, Bajpai R. 2014 - Lichens to Biomonitor the Environment. Springer, New Delhi. Doi: 10.1007/978-81-322-1503-5

Singh P, Singh KP. 2015 - Additional lichen records of Graphidaceae for Manipur, Meghalaya and Nagaland, North- East India. Geophytology 45(2), 181-194.

Singh P, Singh KP. 2016 - New distribution records of lichens for the state of Meghalaya, NorthEast India. Indian Journal of Forestry 39(3), 245-254.

Singh P, Singh KP, Bhatt AB. 2015 - Diversity and distribution of microlichens in the state of Arunachal Pradesh, Eastern Himalaya, India. Check List 11(6), 1-20.

Doi: 10.15560/11.6.1807

Singh KP, Sinha GP. 2010 - Indian lichens: An Annotated Checklist. Bishen Singh Mahendra Pal Singh, Dehradun, India.

Sinha GP, Jagadeesh Ram TAM. 2020 - An overview of the current status of lichen diversity in India and identification of gap areas (Abstract); International Symposium on Plant Taxonomy and Ethnobotany. 13-14 February 2020. Botanical Survey of India, Kolkata.

Sinha GP, Gupta P. 2017 - Studies on microlichens of Sikkim, Eastern Himalaya, India. Nelumbo 59(1), 80-94. Doi: 10.20324/nelumbo/v59/2017/115983

Tripathi SK, Roy A, Kushwaha D, Lalnunmawia F et al. 2016 - Perspectives of Forest Biodiversity Conservation in Northeast India. Journal of Biodiversity, Bioprospecting and Development 3(2), 157. doi:10.4172/2376-0214.1000157

Upreti DK, Debnath R, Uppadhyay V, Raut J. 2014 - Diversity and distribution of lichens in north and west districts of Tripura. Phytotaxonomy 14, 122-129. 